\title{
UU Cipta Kerja, Neoliberalisme, dan Deregulasi
}

\author{
Fuat Edi Kurniawan - detikNews
}

Di tengah krisis akibat pandemi saat ini banyak negara mulai memberlakukan berbagai kebijakan yang lebih agresif terhadap penyebaran virus Covid-19. Berbeda dengan Indonesia, yang dikejar para elite politiknya justru mempercepat pengesahan Omnibus Law yang diklaim sebagai usaha reformasi perekonomian. Hal ini menjadikan kesan bahwa parlemen dan pemerintah mengambil kesempatan di tengah kondisi krisis seolah pandemi sudah usai.

Undang-Undang Omnibus Law atau Cipta Kerja yang baru saja disahkan akan mengatur banyak kluster di berbagai sektor. Sebuah payung hukum yang disetting untuk mengambil segala peran dalam berbagai sektor, padahal tidak sesuai landasan dalam konstitusi Indonesia yang menganut hukum perdata.

Badan legislatif dan pemerintah pun memanfaatkan kekacauan dari kegagalan pemerintahan di tengah krisis Covid-19 untuk mengonsolidasikan kekuatan untuk menyegerakan pengesahan Omnibus Law tanpa campur tangan masyarakat. Terlepas dari kritik dari oposisi, legislatif dan pemerintah bersikeras pada agenda neoliberal ini, mengklaim bahwa tujuan dari UU ini untuk mempromosikan lebih banyak investasi asing (Foreign Direct Investment/FDI) di sektor industri, manufaktur, dan dengan demikian dinilai akan menciptakan lebih banyak lapangan kerja.

Lantas apa dampak agenda neoliberal dalam UU Omnibus Law terhadap kehidupan rakyat di Indonesia? Keputusan pengesahan UU ini menjadi persoalan deregulasi, ideologi hegemonik yang mencakup banyak sektor, dan bukan sekadar kebijakan namun telah menjadi alat pemersatu bagi kelas oligarki yang berkuasa di Indonesia.

UU ini akan memberikan dampak pada pemangkasan ruang penghidupan kelompok nelayan, tani, dan masyarakat adat atas nama kepentingan pembangunan dan ekonomi. Dampaknya akan memberikan kemudahan bagi korporasi dan pemerintah untuk merampas tanah dan sumber daya alam yang dikuasai masyarakat, baik kelompok miskin kota, masyarakat adat, petani, dan nelayan. Akibatnya, mereka berpotensi tak memiliki ruang penghidupan yang bebas dan berdaulat untuk menopang kehidupannya.

\section{Alat Pertumbuhan Ekonomi?}

Selama masa jabatan kedua Presiden Jokowi, narasi tentang pertumbuhan ekonomi dan pentingnya FDI terus dibangkitkan untuk memberikan legitimasi kepada pemerintahannya. Omnibus Law memang merupakan langkah berani dalam upaya mengukir ekonomi pasar terbuka. Padahal UU Omnibus Law dari awal dibangun di atas krisis-naratif. Narasi ini menampilkan manufaktur berbasis FDI sebagai hal yang penting, dan oleh karena itu deregulasi sebagai solusi utama. 
Narasi krisis ini juga telah dipopulerkan oleh Bank Dunia, misalnya dalam laporannya tahun 2019 kepada Jokowi yang menekankan bahwa Indonesia perlu menarik lebih banyak FDI karena jauh dari negara-negara ASEAN lainnya. Laporan tersebut dikatakan mengejutkan Presiden, karena itu dengan cepat memerintahkan para menterinya untuk merevisi undang-undang yang ada dan menyusun Omnibus Law.

Sejak itu, presiden terus menyalahkan buruknya kinerja ekonomi negara pada peraturan yang membingungkan dan birokrasi yang berbelit sehingga membuat investor asing membatalkan rencana investasinya. Di bawah pemerintahan Jokowi, prinsip neoliberal dari pasar nasional yang lebih terbuka dan deregulasi telah diklaim sebagai alat untuk pertumbuhan ekonomi.

Seruan deregulasi menutupi proses material yang menguntungkan kepentingan kelas yang dominan dan memunculkan peran perantara bagi negara. UU Omnibus Law yang baru saja disahkan telah memfasilitasi kelas kapitalis yang berkuasa dan akan membantu mempertahankan praktik akumulasi primitif. Hal ini juga berimbas pada kekuasaan birokratis yang terpusat dan berlawanan dengan semangat desentralisasi/otonomi daerah pasca Reformasi.

UU Cipta Kerja akan menarik kewenangan pemerintah provinsi dalam mengelola mineral dan batubara, termasuk kewenangan penerbitan peraturan daerah dan penerbitan izin. Hal ini menjadikan konsentrasi kekuasaan yang lebih tinggi di tingkat pusat, yang secara efektif mempermudah UU Otonomi Daerah Tahun 2001. Artinya, pemerintah pusat dapat mengubah undang-undang yang berlaku demi penciptaan lapangan kerja melalui Peraturan Pemerintah (PP), melonggarkan standar lingkungan, menerbitkan izin usaha di hampir semua sektor bisnis, dan memasukkan "investasi swasta" melalui SWF (Sovereign Wealth Fund).

\section{Praktik Kekuasaan Orde Baru?}

Trissia Wijaya (2020) dalam artikel Developing Economics menyebutkan bahwa ada hubungan paralel antara deregulasi yang diusulkan dalam UU Omnibus Law dan kebijakan yang didorong oleh kelas kapitalis pada 1990-an. Pada 1990-an Soeharto melakukan serangkaian reformasi termasuk deregulasi dan upaya untuk membuka sektor strategis bagi investasi asing. Kemudian, sektor telekomunikasi mengalami proses deregulasi dan privatisasi.

Undang-undang Telekomunikasi 1989 mensyaratkan kelonggaran kendali negara serta pembatasan masuk pada perusahaan swasta yang ingin mengoperasikan jaringan dan menyediakan layanan non-dasar. Pembatasan dihapus dengan syarat setidaknya dua BUMN, Perumtel dan Indosat, akan memiliki saham di badan usaha baru tersebut.

Tidak ada konsensus tentang apa sebenarnya arti privatisasi atau tentang bagaimana pengadaan akan dilakukan. Hasilnya, sektor tersebut menjadi pelampiasan akumulasi modal yang memadai bagi para elite bisnis yang memiliki koneksi kuat dan keluarga Soeharto yang bermitra dengan perusahaan asing. Selama 
anak-anak Soeharto dan sekutu asingnya bersaing sengit untuk proyek Kerja Sama Operasi (KSO), kontrak akan ditengahi melalui negara.

Konsorsium istimewa negara yang telah menjalin hubungan dengan keluarga Soeharto dan hasil langsungnya adalah negara berbagi rampasan dan menentukan "siapa mendapatkan apa" sebagai pengganti penawaran kompetitif. UU tahun 1989 bisa menjadi sebuah analogi dari paradigma UU Omnibus Law yang mampu mempersatukan kepentingan oligarki dan kelas kapitalis yang menjadi elite politik di Indonesia.

Sebenarnya tidak serta merta bahwa deregulasi tahun 1990 persis sama dengan UU Omnibus Law, tetapi memang terdapat beberapa kesamaan. Terdapat kelanjutan dan proliferasi praktik akumulasi primitif yang dibentuk oleh kelas dominan yang selalu ada, dan praktik ini dilegitimasi melalui mekanisme kebijakan negara yang tersentralisasi.

Kita dapat berharap bahwa UU yang baru disahkan ini perlu dilakukan uji materi melalui mekanisme konstitusional di MK dengan menitikberatkan pada klausul dan pasal-pasal yang cacat. Terutama pada pasal-pasal yang menegasikan posisi rakyat kecil dan mengedepankan kepentingan oligarki dalam praktik kapitalisme dan agenda neoliberalisme. Bagaimanapun, neoliberalisme harus diadili karena kontradiksi dan eksternalitasnya sendiri.

Fuat Edi Kurniawan peneliti di Pusat Penelitian Kependudukan LIPI 